Article

\title{
Biological Control of Aedes albopictus: Obtained from the New Bacterial Candidates with Insecticidal Activity
}

\author{
Handi Dahmana ${ }^{1,2}\left(\mathbb{D}\right.$, Masse Sambou ${ }^{3,4} \oplus^{\circ}$, Didier Raoult ${ }^{1,2}$, Florence Fenollar ${ }^{2,3}$ \\ and Oleg Mediannikov $1,2, *$ (D) \\ 1 IRD, AP-HM, MEPHI, Aix Marseille University, 13005 Marseille, France; \\ handi.dahmana@etu.univ-amu.fr (H.D.); didier.raoult@gmail.com (D.R.) \\ 2 IHU-Méditerranée Infection, 13005 Marseille, France; florence.fenollar@univ-amu.fr \\ 3 IRD, AP-HM, SSA, VITROME, Aix Marseille University, 13005 Marseille, France; massezorro1@gmail.com \\ 4 Campus Commun UCAD-IRD of Hann, Dakar 18524, Senegal \\ * Correspondence: olegusss1@gmail.com; Tel.: +33-(0)4-13-73-24-01; Fax: +33-(0)4-13-73-24-02
}

Received: 26 May 2020; Accepted: 24 June 2020; Published: 29 June 2020

check for updates

\begin{abstract}
Vector-borne deadly pathogens cause more than 700,000 deaths annually. They are transmitted by several vectors, among which the mosquito is the most important. Chemical compounds often have devastating side effects, leading to the abandonment of the majority of them. Biological control has been performed by using formulations of Bacillus sphaericus and Bacillus thuringiensis, but their intensive use has led to the emergence of resistance. Currently, the development of new alternative molecules is urgently needed, in order to use them in mosaics or in rotation with already known insecticides for the control of vectors, especially mosquitoes. Here, we attempted to identify bacterial species with potential anti-mosquito actions. Among bacterial strains isolated from dry sandy soil from Senegal, eleven strains from the Bacillales and Actinomycetales orders were chosen for the entomopathogenic activity experiments. Then, we tested their secondary metabolites, which were obtained from the supernatant fraction, and their cell wall and cytoplasmic compounds, which were found in the pellet fraction, in Aedes albopictus larvae, and compared the larval mortality rate with that obtained by using a commercial product. A total of $4 / 11(36.36 \%)$ of the isolated species exhibited insecticidal activity. B. nealsonii, which is not a well-known bacterium, had the highest larvicidal effect with $70 \%$ of the larval mortality, which is highlighted for the first time. The Streptomyces species we isolated seem to be potential new species, and 3/5 (60\%) of them exhibited insecticidal activity. Our study reports provide potential candidates for the identification of active molecules to be developed for strengthening the biological control of infectious diseases agents transmitted by mosquitoes.
\end{abstract}

Keywords: mosquito borne diseases; biological control; soil bacteria; secondary metabolites; insecticide

\section{Introduction}

Vector-borne deadly diseases account for more than $17 \%$ of all infectious diseases; among them, 700 million people are infected and more than a million die each year from mosquito-borne illness. Dengue fever is one of the most threatening and up to 4 billion people in more than 128 countries are at risk, which results in an estimated 96 million cases annually [1-4]. Malaria remains the greatest killer, although great progress has been made in combating malaria in the past two decades; however, its agents still result in millions of cases and thousands of deaths annually (more than 193 million cases in 2017) [5]. Ticks, black flies, sandflies, midges, fleas and triatomine bugs are important vectors of 
pathogens affecting humans [6], but mosquitoes are still the most well known and most dangerous vector of devastating pathogens.

Dangerous pathogens are transmitted by Aedes mosquitoes, such as dengue, Zika and chikungunya, which have accumulated very significant gains in recent years, while old threats, such as yellow fever and Japanese encephalitis, have re-emerged $[7,8]$. A large number of chemical compounds are used to control them. However, the heavy use of these chemical products has led to several dramatic drawbacks, such as the contamination of water and food sources, the poisoning of nontarget fauna and flora, their concentration in the food chain and emergence of insecticide resistance [9]. When compared to the control strain (not exposed), several studies reported the insecticide susceptibility decrease in Aedes sp. associated to resistance development reaching $23 \%$ reduction in mortality observed after six generations and around $77 \%$ after eight generations [10]. Because of this, the research community has turned away from these molecules and has instead committed to biological control.

More than a thousand naturally occurring microorganisms have been identified as potential insecticidal agents so far, and secondary metabolites from 942 microbial isolates were screened for their insecticidal properties, most of which were bacteria from the Bacillus and Streptomyces genera [11,12]. In fact, formulations of live B. sphaericus and B. thuringiensis bacteria are the predominant nonchemical products [13]. However, their intensive use has led to the frequent occurrence of resistance [14,15]. That is why numerous studies are continuously conducted to isolate large collections of Bacillus or Streptomyces strains to examine their biological activities, including antibacterial, insecticide and other activities [16-24].

In our study, we performed the isolation of bacterial strains from a dry sandy soil in Senegal and targeted mostly Bacillus and Streptomyces species as potential candidates, and we subsequently tested fractions of the supernatant and the pellet against Aedes albopictus larva. Metabolites derived from wild bacteria may contain a very large number of molecules with unknown properties, including those with insecticidal effects like those that we are seeking in this study. We aimed to find new bacterial candidates that may be used for the development of insecticidal tools for the biological control of infectious diseases agents transmitted by vectors.

\section{Materials and Methods}

\subsection{Soil Sampling}

Approximately $30 \mathrm{~g}$ of sandy soil (Figure 1) was collected with a sterile spatula at a depth of approximately $10 \mathrm{~cm}$. The sample was then placed in a sterile urine collection vial and stored at room temperature during transport. The samples were stored at $-80^{\circ} \mathrm{C}$ in (IHU-Méditerranée Infection, Marseille, France) until further experiments.

\subsection{Bacterial Isolation}

The sample was thawed immediately before isolation, homogenized (total homogenization by shaking) and then two times $1 \mathrm{~g}$ was taken and mixed in $10 \mathrm{~mL}$ of sterile distilled water. Then, the contents were incubated for $24 \mathrm{~h}$ at room temperature. Thereafter, the supernatant was recovered and homogenized, and ten serial $1 / 10$ dilutions were performed. The inoculum $(50 \mu \mathrm{L})$ was seeded on Columbia agar supplemented with 5\% sheep blood (bioMérieux, Marcy l'Etoile, France) in actinomycetes isolation agar (Merck, Darmstadt, Germany) and then incubated under aerophilic conditions at $32{ }^{\circ} \mathrm{C}$ for at least $48 \mathrm{~h}$ for Bacillus spp. isolation and for at least 1 week for Streptomyces spp. isolation.

\subsection{Strains Identification}

Bacterial species were directly identified from each bacterial colony using matrix-assisted laser desorption ionization-time mass spectrometry (MALDI-TOF MS) (Bruker Daltonics, Bremen, Germany) as previously described [25]. A score of $>2$ allowed identification at the species level, and a score of 
$<1.7$ did not allow any identification. In this case, $16 \mathrm{~S}$ rRNA gene was amplified and the amplicon sequenced. Briefly, DNA extraction was performed using EZ1 DNA kits (Qiagen, Courtaboeuf, France), according to the manufacturer's protocol. Amplification and sequencing were performed as described in the study by Dahmana et al. [26] using the 16S universal primers [27].

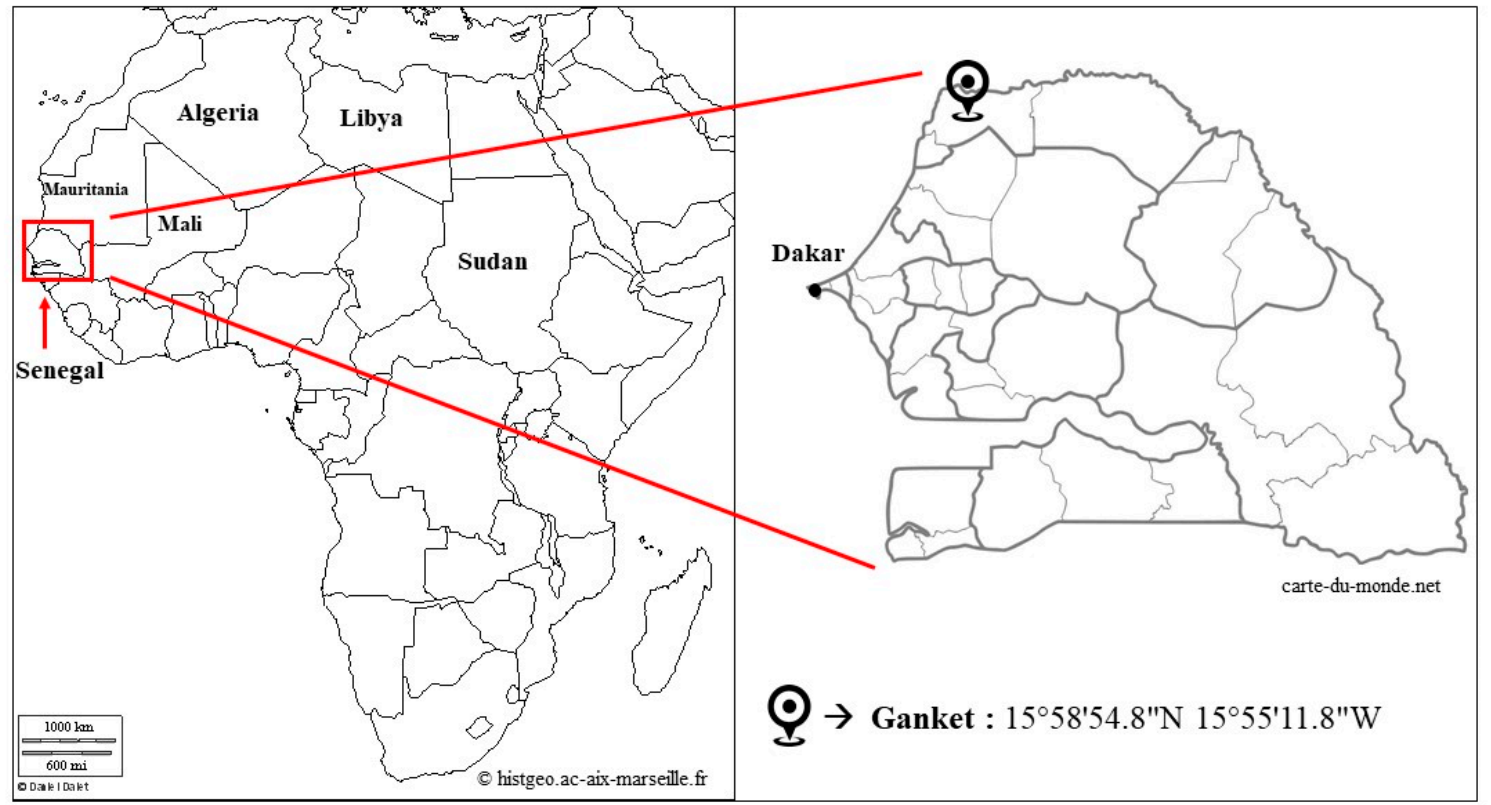

Figure 1. Site of sandy soil sampling in Ganket village, Senegal.

To obtain the MALDI-TOF spectra of Streptomyces species, first, treatment of hard stained colonies on agar was performed with Tissue Lyser (QIAGEN, MD, USA) and tungsten beads for at least 3 min to obtain isolated bacteria, which were suspended in distilled water. Liquid cultures $(5 \mathrm{~mL})$ were then generated using the bacterial suspension. Two milliliters of liquid culture were centrifuged at $17,000 \times g$ for $5 \mathrm{~min}$. The supernatant was discarded and the bacterial pellets were recovered. Subsequently, we performed the extraction of proteins by using an ethanol-formic acid extraction procedure [28]. Briefly, we aliquoted $300 \mu \mathrm{L}$ of the suspended bacteria in distilled water and added $900 \mu \mathrm{L}$ ethanol. Subsequently, the cell suspension was centrifuged at $17,000 \times g$ for 2 min and the supernatant discarded. The centrifugation was repeated and the residual ethanol discarded. The pellet was air-dried and thoroughly resuspended in 5 to $50 \mu \mathrm{L}$ formic acid-water (70:30 [vol/vol]), depending on its size, and finally, an equal volume of acetonitrile was added. After centrifugation at 17,000× $g$ for $2 \mathrm{~min}, 1 \mu \mathrm{L}$ of the supernatant was transferred to a polished steel MSP 96 target plate (Bruker Daltonics) and allowed to dry at room temperature before being overlaid with $1 \mu \mathrm{L}$ of a saturated a-cyano-4-hydroxy-cinnamic acid (HCCA) matrix solution in 50\% acetonitrile-2.5\% trifluoroacetic acid (Bruker Daltonik). Finally, the matrix sample was crystallized by air-drying it at room temperature for $5 \mathrm{~min}$.

The spectra generated by MALDI-TOF MS without initial identification were recovered to control their quality. After validation of the spectra by using the Bruker software, the MALDI Biotyper 3.0 software was used to build dendrograms that allowed the comparison of the different isolates. The $16 \mathrm{~S}$ rRNA-based phylogenetic reconstruction does not guarantee well-resolved and robust trees that reflect the overall relationship between Streptomyces species, accordingly, to identify the Streptomyces strains, the 23S rRNA [29] and atpD [30] genes were amplified, and the amplicons were sequenced as described in the study by Dahmana et al. [26]. The electropherograms obtained were assembled and edited using ChromasPro 1.7.7 software (Technelysium Pty Ltd., Tewantin, Australia) and the sequences obtained were compared with those available in the GenBank database by NCBI BLAST (http://blast.ncbi.nlm.nih.gov/Blast.cgi). For taxonomic analyses, the maximum-likelihood phylogenetic trees were constructed using MEGA software version 7.0.21 [31] with 100 bootstrap replications and 
the species position confirmed using Topali software version V2.5 (2.5.13.04.03) [32]. More specific information is found in the figures.

\subsection{Fractions Preparation}

The strains were stored at $-80{ }^{\circ} \mathrm{C}$. The cultures were grown on solid Columbia agar medium with $5 \%$ sheep blood (bioMérieux) under aerobic conditions at $32{ }^{\circ} \mathrm{C}$. Thereafter, several colonies were transferred in sterile conditions into $1 \mathrm{~L}$ of liquid Tryptic soy broth medium (Sigma-Aldrich, France), which was incubated for 3 days for Bacillus spp. and for 14 days for Streptomyces spp. at $32{ }^{\circ} \mathrm{C}$ and $110 \mathrm{rpm}$ in a shaker incubator under aerobic conditions.

The supernatant-pellet separation was carried out by centrifugation at $8000 \times g$ for 20 min at $4{ }^{\circ} \mathrm{C}$ using an A98813 J-Lite PP bottle assembly with a JLA-8.1000 rotor (Beckman Coulter, Villepinte, France). After centrifugation, the supernatant was immediately filtered through a $0.45 \mu \mathrm{m}$ filter and placed into $75 \mathrm{~mL}$ flasks, after which it was frozen horizontally overnight at $-80^{\circ} \mathrm{C}$ and then lyophilized the next day. The lyophilizate was stored at $-20^{\circ} \mathrm{C}$ prior to the assays.

\subsection{Release of Inclusions and the Main Cell Components}

After centrifugation, the pellet was resuspended in PBS and $700 \mu \mathrm{L}$ of the resuspension was distributed into $2 \mathrm{~mL}$ cryotubes (Bio-One $\mathrm{GmbH}$, Rainbach im Mühlkreis, Austria). In order to exclude the effects of live bacteria on future experiments, we disintegrated the bacteria by consecutive freezing/thawing and sonication treatments. Each tube was subjected to three freeze-thaw cycles for $5 \mathrm{~min}$ each using liquid nitrogen and a hybridization incubator heated to $50{ }^{\circ} \mathrm{C}$. The tubes were centrifuged at $13,000 \times g$ for $10 \mathrm{~s}$, and the contents were transferred into $1.5 \mathrm{~mL}$ Eppendorf Safe-Lock tubes (Eppendorf, Montesson, France) and then subjected to 3 sonication cycles at an amplitude of $50 \mathrm{~Hz}$ for $30 \mathrm{~s}$. Subsequently, ultracentrifugation was carried out at $20,000 \times g$ for $20 \mathrm{~min}$ at $4{ }^{\circ} \mathrm{C}$. Thereafter, the supernatant was recovered, directly filtered through a $0.45 \mu \mathrm{m}$ filter and stored at $-20{ }^{\circ} \mathrm{C}$ prior to the assays. All fractions were regularly cultured on Columbia sheep blood agar plates (bioMérieux) after filtration to ensure their sterility.

\subsection{Fractions Used in Larval Assays}

Once the larvae were ready (third and early fourth instar), the sterile fractions (pellet and supernatant) already prepared of a bacteria strain were thawed at room temperature, after which the Bradford protein assay (BIO-RAD, Schiltigheim, France) was carried out. Subsequently, the volume of the fraction used was adjusted to have two concentrations, 2 and $6 \mathrm{mg} / \mathrm{L}$, which were administered to the larvae. We tested the supernatant and pellet fractions of each stain separately at concentrations of 2 and $6 \mathrm{mg} / \mathrm{L}$. We also tested the mixture of each of the two fractions at $6 \mathrm{mg} / \mathrm{L}$ to determine if there was a synergetic effect of the secreted and cell constituent compounds.

We used Bacillus thuringiensis subsp. israelensis AM65-52 (Bti), which was isolated from a commercial granular formulation (VectoBacGR, Valent Bioscience, Libertyville, IL, USA), to validate our protocol and to assess the insecticidal activity of the strain used as a positive control. Thus, in both the studied bacterial strains and in positive controls, we eliminated the direct effect of live bacteria on mosquito larvae (only sterile fractions were tested). We administered the bacterial fractions $24 \mathrm{~h}$ before feeding the larvae to give them enough time to ingest the bacterial fraction compounds.

\subsection{Screening for Insecticidal Activity}

The Aedes albopictus laboratory colony was maintained at $27 \pm 0.5^{\circ} \mathrm{C}$ and in $80 \pm 5 \%$ relative humidity. Adult mosquitoes were maintained with constant exposure to $10 \%$ sterile sucrose on cotton balls that were changed daily. For egg production, adult female mosquitoes were given defibrinated human blood (French Blood Agency, France) via the Haemotek membrane feeding system (Haemotek Ltd., Blackburn, UK). Larvae were fed Tetra-Min (Spectrum Brands, Fennimore, WI, USA) fish food in clear water until the pupae stage. 
Seventy-five milliliter flasks were used for the insecticide screening assays. Only third and early fourth instar larvae were used in the insecticidal activity assays. All tests of each fraction were performed with 25 larvae $(\mathrm{N}=4)$, and a total of 100 larvae for each fraction were tested as recommended by the WHO [33]. Immediately after separating the larvae in flasks containing $100 \mathrm{~mL}$ of clean distilled water, we added the calculated volume of insecticide. Larvae were not fed until the 24th hour. Dead larvae were counted at 24, 48 and $72 \mathrm{~h}$. In each assay, 100 larvae were used as negative controls, which did not receive any fraction, to assess natural mortality. We considered that a strain had a good insecticidal activity if it induced $>20 \%$ mortality.

\subsection{Data Analysis}

We used the Epi Info version 7 program (http://www.cdc.gov/epiinfo/index.html) (Addinsoft, 2019) and the XLSTAT statistical and data analysis solution (Paris, France, https://www.xlstat.com) to perform the statistical analyses. The Kruskal-Wallis test, the comparison of k-proportions test and the pairwise comparison test were performed to compare the mortality rates recorded at $72 \mathrm{~h}$ after administration of $6 \mathrm{mg} / \mathrm{L}$ of each supernatant fraction. A difference was statistically significant when the $p$-value was $\leq 0.05$. The Dunn procedure (bilateral test) was performed to separate groups of strains according to their efficiencies against $A$. albopictus larva. The total number of living A. albopictus larvae was transformed to the arithmetic means. The insecticidal effects were calculated at $72 \mathrm{~h}$ for each active fraction using Abbott's formula (Abbott, 1987) as follows:

$$
\text { Insecticidal efficacy }(\%)=100 * \frac{N C i-N T i}{N C i} .
$$

where NCi and NTi represent the geometric mean (GM) of living A. albopictus in the control and treated groups, respectively.

\section{Results}

\subsection{Isolated Strains}

Four Bacillus strains were directly identified by MALDI-TOF MS, while the strain Sen140 was not identified by mass spectrometry, although a good quality spectrum was obtained that did not match any spectra in the MALDI-TOF database. Subsequently, for the strain Sen140, the 16S gene was sequenced and deposited in GenBank (accession number: MN788519). Streptomyces strains could not be identified by MALDI-TOF either by the direct method or by the direct ethanol-formic acid extraction method [34]. Using the optimized protocol (see above), good-quality spectra were obtained (Figure S1), but identification could not be achieved because of the lack of Streptomyces spectra in the database. The dendrogram built using MALDI Biotyper 3.0 software permitted the comparison of the different Streptomyces spectra (Figure 2). The analysis of the sequences of the atpD (Figure 3) and $23 \mathrm{~S}$ rRNA (Figure 4) genes showed that the Streptomyces strains isolated in this study may represent potential new species.

The accession numbers of the $23 \mathrm{~S}$ and atpD genes were obtained and are shown in Table S2. For the following experiments, we chose bacteria from the Bacillus, Brevibacillus, Micrococcus and Streptomyces genera representing 11 strains (Table 1).

\subsection{Screening for Insecticidal Activity}

A total of 108 strains from 15 different genera were isolated. Because Actinomycetales and Bacillales are known for their production of compounds exhibiting entomopathogenic activity, we focused our study on strains belonging to both of these orders, corresponding to eleven strains that were chosen for the entomopathogenic activity experiments. The secondary metabolites of these strains were produced, concentrated and then screened for insecticidal activity. The overall results are presented in Table 2. We noticed for all strains that insecticidal activity caused by the main cell components was 
absent and that mosquito larvae mortality caused by the supernatants was dose-dependent. When tested at a concentration of $6 \mathrm{mg} / \mathrm{L}$, supernatants from $36.4 \%(4 / 11)$ of the bacterial strains exhibited activity against the $A$. albopictus larvae. Regarding negative control and throughout the testing periods, no larva was found dead.

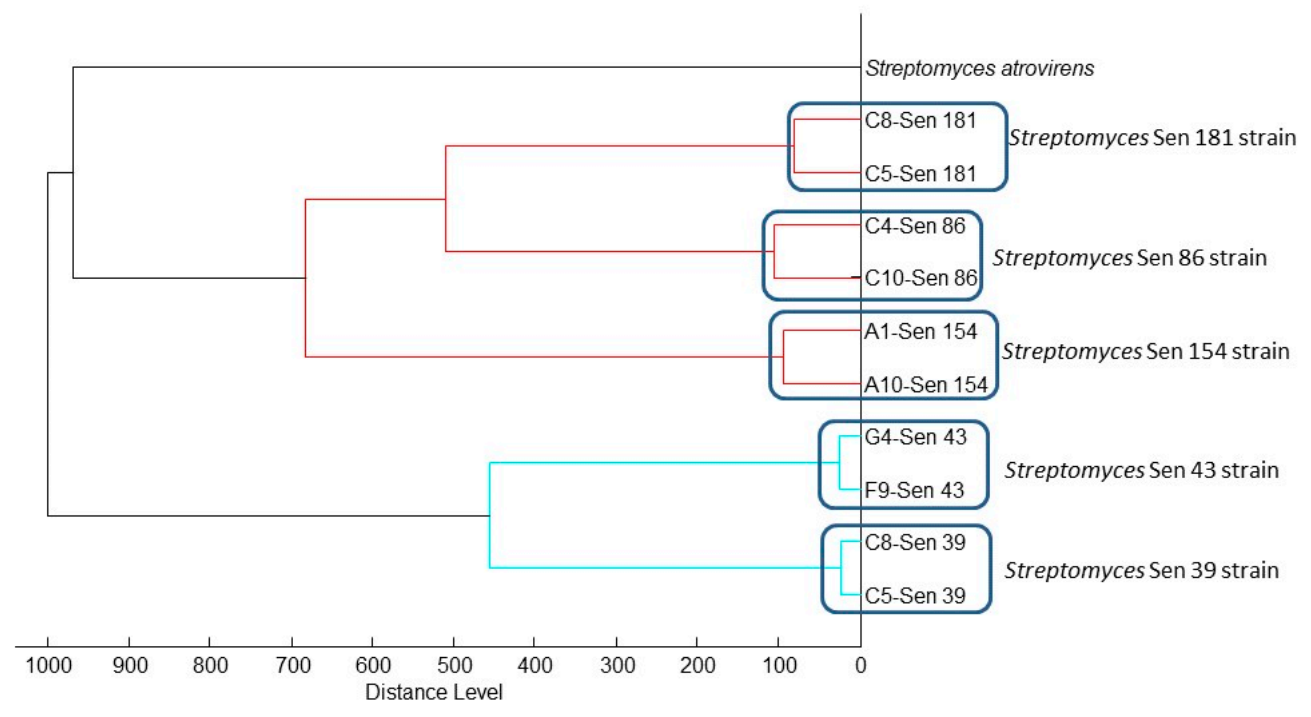

Figure 2. Dendrograms for the Streptomyces strains generated using the MALDI Biotyper 3.0 software, with Streptomyces atrovirens as the outgroup.

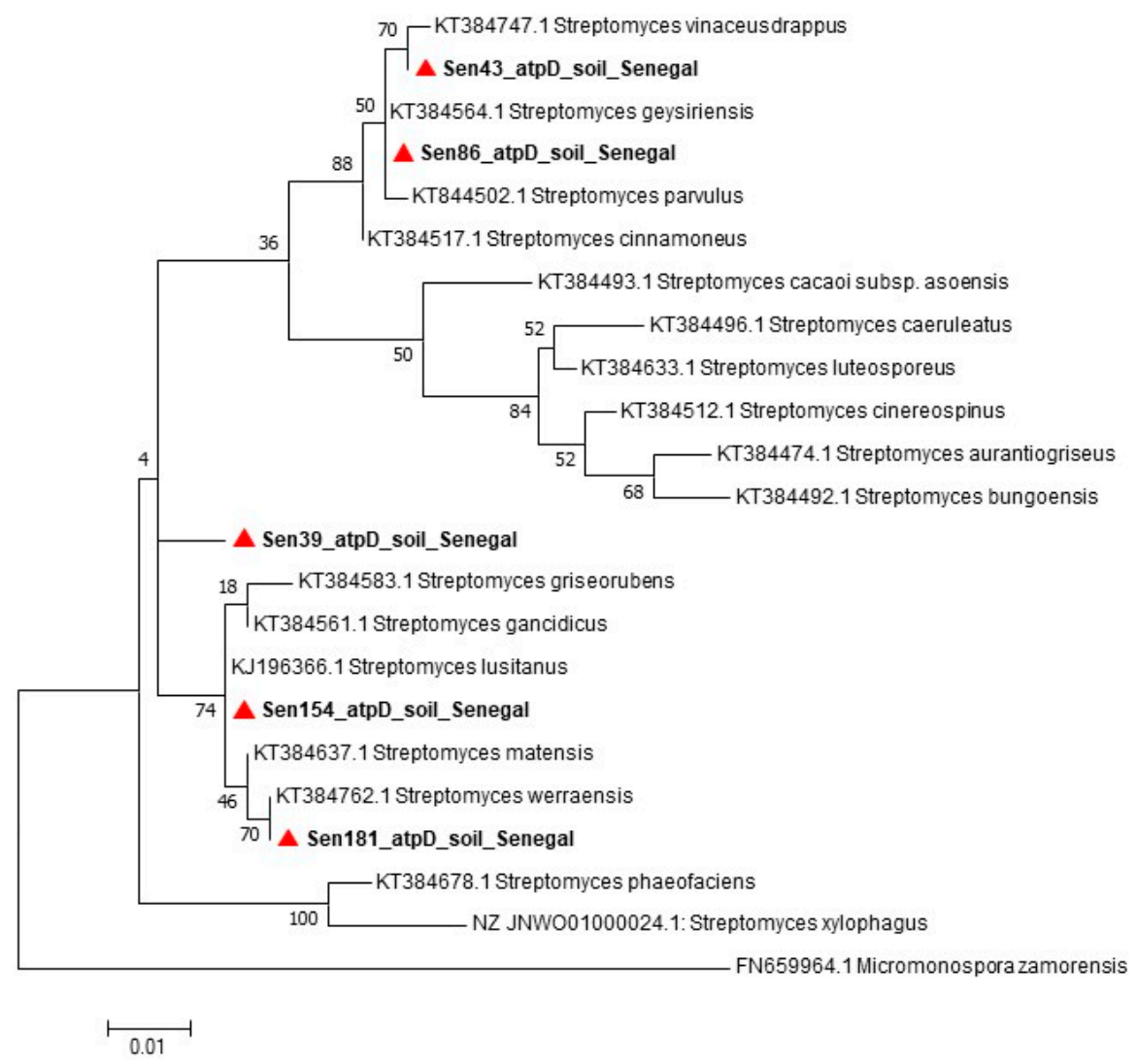

Figure 3. Maximum-likelihood phylodendrogram of Streptomyces spp., including the species isolated in the present study based on the partial 466-bp sequence of the atpD gene. 


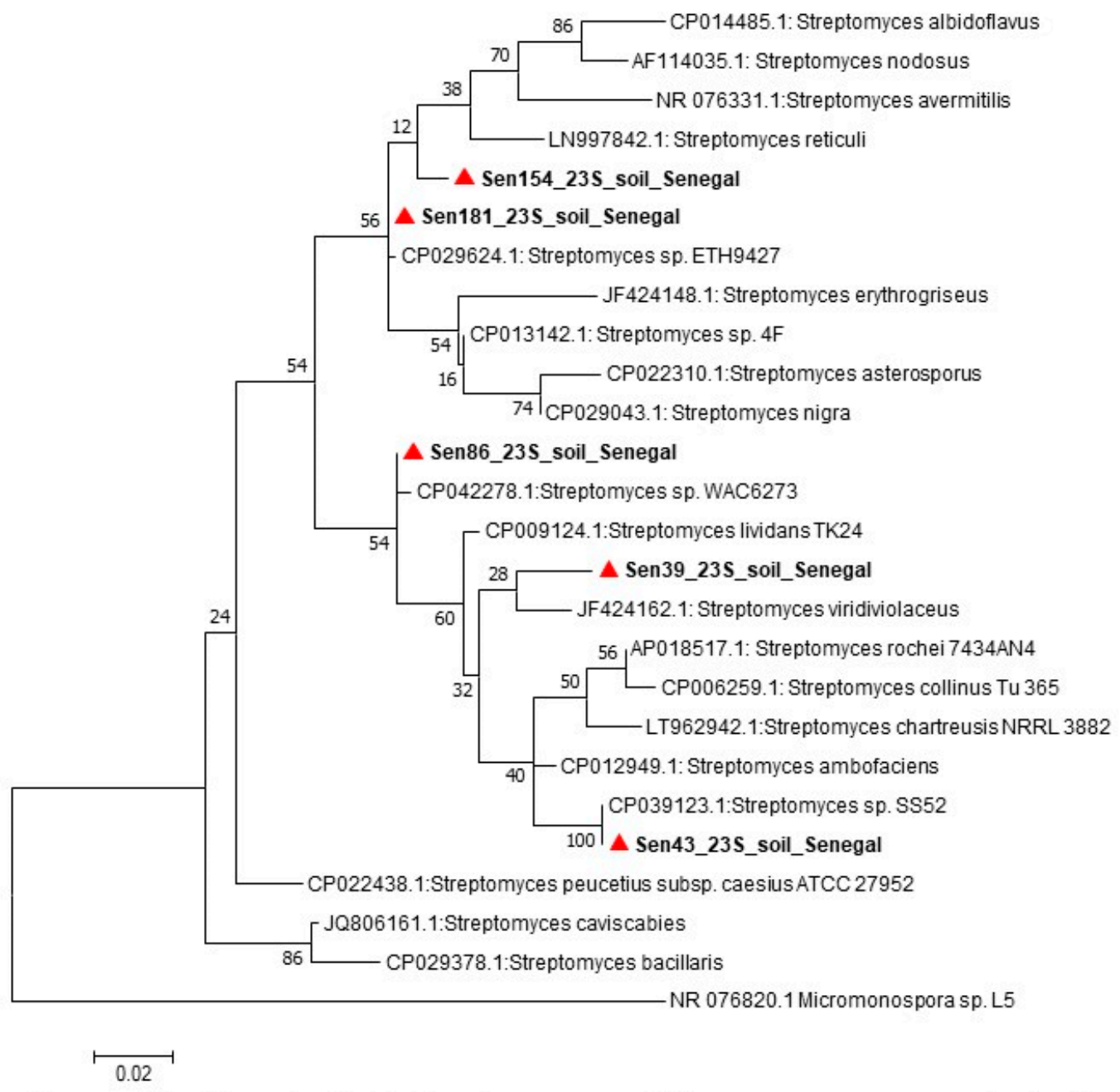

Figure 4. Maximum-likelihood phylodendrogram of Streptomyces spp., including the species isolated in the present study based on the partial 1000-bp sequence of the 23S rRNA gene.

Table 1. Isolated strains used in the study.

\begin{tabular}{ccc}
\hline Order & Genus and Species & Strain Code \\
\hline$\frac{\text { Actinomycetales }}{\text { Actinomycetales }}$ & Streptomyces sp. & Sen 181 \\
\hline$\frac{\text { Actinomycetales }}{\text { Actinomycetales }}$ & Streptomyces sp. & Sen 43 \\
\hline Actinomycetales & Streptomyces sp. & Sen 154 \\
\hline Bacillales & Streptomyces sp. & Sen 86 \\
\hline Bacillales & Brevibacillus brevis & Sen 108 \\
\hline Actinomycetales & Bacillus nealsonii & Sen 132 \\
\hline Bacillales & Bicrococcus luteus & Sen 7 \\
\hline Bacillales & Bacillus pumilus subtilis & Sen 186 \\
\hline Bacillales & Bacillus sp. & Sen 66 \\
\hline
\end{tabular}


Table 2. Detailed results of the insecticidal activity of the secondary metabolites of the isolated species against third and early fourth instar A. albopictus larvae at $72 \mathrm{~h}$ post-administration.

\begin{tabular}{|c|c|c|c|c|c|c|c|}
\hline \multirow{2}{*}{ Species } & \multirow{2}{*}{ Strain } & \multirow{2}{*}{$\begin{array}{l}\text { Negative } \\
\text { Control }\end{array}$} & \multirow{2}{*}{$\frac{\text { Pellet }}{(2-6 \mathrm{mg} / \mathrm{L})}$} & \multicolumn{2}{|c|}{ Supernatant } & \multirow{2}{*}{$\begin{array}{l}\text { Supernatant + } \\
\text { Pellet }(6 \mathrm{mg} / \mathrm{L}) \text { * }\end{array}$} & \multirow{2}{*}{ Notes } \\
\hline & & & & $2 \mathrm{mg} / \mathrm{L}$ & $6 \mathrm{mg} / \mathrm{L}$ & & \\
\hline $\begin{array}{l}\text { Streptomyces } \\
\text { sp. }\end{array}$ & Sen 181 & $0 \%$ & $0 \%$ & $0 \%$ & $18 \%$ & $20 \%$ & $\begin{array}{c}\text { No potential } \\
\text { Insecticidal activity }\end{array}$ \\
\hline $\begin{array}{l}\text { Streptomyces } \\
\text { sp. }\end{array}$ & Sen 43 & $0 \%$ & $0 \%$ & $0 \%$ & $12 \%$ & $8 \%$ & $\begin{array}{c}\text { No potential } \\
\text { Insecticidal activity }\end{array}$ \\
\hline $\begin{array}{l}\text { Streptomyces } \\
\text { sp. }\end{array}$ & Sen 154 & $0 \%$ & $0 \%$ & $29 \%$ & $31 \%$ & $28 \%$ & $\begin{array}{l}\text { Potential Insecticidal } \\
\text { activity }\end{array}$ \\
\hline $\begin{array}{l}\text { Streptomyces } \\
\text { sp. }\end{array}$ & Sen 86 & $0 \%$ & $0 \%$ & $35 \%$ & $41 \%$ & $32 \%$ & $\begin{array}{c}\text { Potential Insecticidal } \\
\text { activity }\end{array}$ \\
\hline $\begin{array}{l}\text { Streptomyces } \\
\text { sp. }\end{array}$ & Sen 39 & $0 \%$ & $0 \%$ & $30 \%$ & $36 \%$ & $40 \%$ & $\begin{array}{c}\text { Potential Insecticidal } \\
\text { activity }\end{array}$ \\
\hline $\begin{array}{l}\text { Brevibacillus } \\
\text { brevis }\end{array}$ & Sen 108 & $0 \%$ & $0 \%$ & $0 \%$ & $2 \%$ & $4 \%$ & $\begin{array}{c}\text { No potential } \\
\text { Insecticidal activity }\end{array}$ \\
\hline $\begin{array}{l}\text { Bacillus } \\
\text { nealsonii }\end{array}$ & Sen 132 & $0 \%$ & $0 \%$ & $40 \%$ & $70 \%$ & $84 \%$ & $\begin{array}{c}\text { Potential Insecticidal } \\
\text { activity }\end{array}$ \\
\hline $\begin{array}{l}\text { Micrococcus } \\
\text { luteus }\end{array}$ & Sen 7 & $0 \%$ & $0 \%$ & $4 \%$ & $4 \%$ & $12 \%$ & $\begin{array}{c}\text { No potential } \\
\text { Insecticidal activity }\end{array}$ \\
\hline $\begin{array}{l}\text { Bacillus } \\
\text { pumilus }\end{array}$ & Sen 186 & $0 \%$ & $0 \%$ & $5 \%$ & $6 \%$ & $4 \%$ & $\begin{array}{c}\text { No potential } \\
\text { Insecticidal activity }\end{array}$ \\
\hline Bacillus subtilis & Sen 66 & $0 \%$ & $0 \%$ & $10 \%$ & $10 \%$ & $12 \%$ & $\begin{array}{c}\text { No potential } \\
\text { Insecticidal activity }\end{array}$ \\
\hline Bacillus sp. & Sen 140 & $0 \%$ & $0 \%$ & $4 \%$ & $6 \%$ & $8 \%$ & $\begin{array}{c}\text { No potential } \\
\text { Insecticidal activity }\end{array}$ \\
\hline $\begin{array}{c}\text { Bacillus } \\
\text { thuringiensis }\end{array}$ & AM65-52 & $0 \%$ & $0 \%$ & $15 \%$ & $33 \%$ & $34 \%$ & Insecticidal activity \\
\hline
\end{tabular}

The most active species was Bacillus nealsonii Sen 132, which resulted in $70 \%$ larval mortality that was increased to $84 \%$ when it was mixed with the pellet fraction. The activity of the other species was as follows: Streptomyces sp. Sen 86 resulted in $41 \%$ larval mortality, Streptomyces sp. Sen 39 resulted in $36 \%$ larval mortality and Streptomyces sp. Sen 154 resulted in $31 \%$ larval mortality. We noticed that for most of the species, the rate of larval mortality did not change considerably when the supernatant was combined with the pellet fraction (Table 2). Among the rest of the species, $63.6 \%(7 / 11)$ were not active or had the lowest activity against the mosquito larvae, resulting in $\leq 20 \%$ mortality (Table 2 ). When comparing the insecticidal activity of the supernatant fractions from those of the different strains at $72 \mathrm{~h}$ with $6 \mathrm{mg} / \mathrm{L}$, the difference was significant (critical value of $\mathrm{khi}^{2}=19,675, p$-value $\leq 0.0001$ ). The comparison of the insecticidal activity performed included the reference strain (Table S1).

The efficacy of the strains was compared to that of the Bti positive control (Table 3). We used this strain as a control for several reasons. It produces different Cry toxins that, after ingestion, are able to form pores in the plasma membrane of midgut epithelial cells in susceptible insects [35]. Using the Dunn test, the strains were classified into four groups according to their efficiencies (Paris, France, https://www.xlstat.com). Group D was the most effective, as it was composed of only the B. nealsonii species, which had a mortality rate more than twice that of the positive control, with a mean rank equal to 887.5. Group C, which was composed of the three other active species and the positive control, had a mortality rate ranging from $31 \%$ to $41 \%$, and a mean rank ranging from 647.5 to 713.5 . The $\mathrm{B}$ and $\mathrm{C}$ groups were mostly comparable, while group A was the least effective and was composed of the strains with the lowest activity and effectiveness (Table S1), and with mean ranks ranging from 479.5 to 575.5 . 
Table 3. Comparison of the efficacy of the strains to that of the positive control Bti.

\begin{tabular}{cccccccc}
\hline Strain & Code & Mortality Rate & Standard Deviation & Groups & Mean Rank & $p$-Value & \multicolumn{2}{c}{ Significance } \\
\hline Bti & AM65-52 & $\mathbf{3 3} \%$ & Ref & B-C & Ref & Ref & Ref \\
\hline Streptomyces sp. & Sen 181 & $18 \%$ & 0.386 & A-B & 90 & 0.011 & Neg. S** \\
\hline Streptomyces sp. & Sen 43 & $12 \%$ & 0.302 & A & 138 & $\leq 0.0001$ & Neg. S** \\
\hline Streptomyces sp. & Sen 154 & $31 \%$ & 0.461 & B-C & 18 & 0.610 & NS *** \\
\hline Streptomyces sp. & Sen 86 & $41 \%$ & 0.494 & C & -48 & 0.173 & NS *** \\
\hline Streptomyces sp. & Sen 39 & $36 \%$ & 0.482 & B-C & -18 & 0.610 & NS *** \\
\hline Brevibacillus brevis & Sen 108 & $2 \%$ & 0.141 & A & 186 & $\leq 0.0001$ & Neg. S** \\
\hline Bacillus nealsonii & Sen 132 & $70 \%$ & 0.461 & D & -222 & $\leq 0.0001$ & Pos. S* \\
\hline Micrococcus luteus & Sen 7 & $4 \%$ & 0.197 & A & 174 & $\leq 0.0001$ & Neg. S \\
\hline Bacillus pumilus & Sen 186 & $6 \%$ & 0.239 & A & 162 & $\leq 0.0001$ & Neg. S \\
\hline Bacillus subtilis & Sen 66 & $10 \%$ & 0.302 & A & 138 & $\leq 0.0001$ & Neg. S ** \\
\hline Bacillus sp. & Sen 140 & $6 \%$ & 0.239 & A & 162 & $\leq 0.0001$ & Neg. S** \\
\hline
\end{tabular}

The insecticidal activity of only one species, B. nealsonii Sen 132, was significantly increased, and it killed more than $2 / 3$ of $A$. albopictus larval, whereas the reference strain Bti killed only $33 \%$. Furthermore, B. nealsonii Sen 132 was much more active compared to the other strains in group A isolated in this study.

\section{Discussion}

A total of 108 strains from 15 different genera were isolated. Because Actinomycetales and Bacillales are known for their production of compounds exhibiting entomopathogenic activity, we focused our study on testing strains belonging to both of these orders. Eleven strains were tested for their insecticidal activity by using A. albopictus larvae. Insect-borne diseases cause hundreds of thousands of deaths in humans every year, and mosquitoes such as Aedes species are among the most important vectors of these deadly pathogens [12,36-38].

The search for new insecticidal molecules is a global need due to the re-emergence of deadly disease vectors, the control of which depends on identifying new insecticidal molecules [38]. The widespread emergence of insecticide resistance complicates this mission concerning essential chemical compounds due to several factors, one being species fitness [39]. Furthermore, we know that such compounds are key for the control of diseases such as malaria, which is currently threatened by resistance development that has been reported in over $80 \%$ of countries with endemic malaria [40]. For its various positive points, biological control has become more common and has attracted a great deal of attention [12].

Streptomyces are Gram-positive bacteria and are the largest representative genus of actinomycetes, which are found mostly in soil [41]. They are industrially useful microorganisms that produce a wide variety of antibiotics, and several studies have been carried to investigate their biological effects [42-44]. Species of the Bacillus genus are generally also found in soil, and they have many benefits [45], especially for crop improvement, due to biomolecular changes in adverse environments [46], defense against vectors of infectious diseases [47] and antimicrobial properties [20]. For this purpose, different studies were carried out involving the isolation of bacteria from the soil for biological effects research $[20,22,24,45]$. A study was carried out in Senegal to search for strains of B. thuringiensis and B. sphaericus useful for the control of malaria, which revealed that 27/203 (13.3\%) of strains were active [48]. Currently, many studies report resistance to the latter species [49-51], and we must seek better solutions. We focused on secreted metabolites and the components of bacterial cell walls or cytoplasm. Eleven different strains of Bacillus $(\mathrm{N}=5)$, Micrococcus $(\mathrm{N}=1)$ and Streptomyces $(\mathrm{N}=5)$ were chosen for further studies for the identification of insecticidal activity. 
Secondary metabolites were produced and separated into two fractions. The supernatant fraction contained the secreted metabolites and the pellet fraction contained the cell wall and cytoplasmic metabolites. Then, screening for insecticidal activity was carried out and $36.4 \%(4 / 11)$ of the strains showed insecticidal activity that killed more than $20 \%$ of $A$. albopictus larvae during testing of the supernatant fraction (given the very small amount of material tested); a mortality greater than $20 \%$ is considered promising (the use of a pure compound will give better activity).

Several projects studied large collections of Bacillus species to identify direct biological activity, including insecticidal activity [20-22,24], and numerous other Bacillus spp. show high toxicity against dipterans, such as Bacillus circulans [52] and Brevibacillus laterosporus [53,54]. Although many Bacillus strains were tested previously, it is clear that numerous species remain undiscovered and not officially described $[55,56]$. B. nealsonii was already isolated from potentially hostile environments, including a spacecraft assembly and the rumen of a buffalo [57,58], and it is not well characterized or shown great usefulness except for its very limited application to the production of proteases and as an additive detergent $[59,60]$. The secondary metabolites of the strain Sen132 of B. nealsonii that we isolated were screened for mosquitocidal activity and exhibited high activity against $A$. albopictus larvae. A total of $70 \%$ of the third and fourth instar larvae were killed in less than $72 \mathrm{~h}$ by the supernatant fraction, showing that these strains secrete a potential insecticidal compound in the culture medium. Further studies are needed to characterize the active compounds of these good bacterial candidates as agents for the biocontrol of mosquitoes, which we have demonstrated for the first time. The other species of the Bacillus genus that we tested had no or low larvicidal activity. This may mean that these species do not produce insecticidal molecules or that the optimization of the necessary parameters to ensure their optimal production is required, as our production protocol was standardized for all the bacteria used in this study.

Additionally, the supernatant fractions of three $(60 \%)$ of the five species of Streptomyces that we isolated exhibited good insecticidal activity, which is comparable to that produced by the positive control Bacillus thuringiensis subsp. israelensis AM65-52 that was isolated from a commercial granular formulation. Numerous studies have already carried out the isolation of Streptomyces bacteria from soil to look for potential insecticidal effects on different insects of agronomic or public health interest [17-19,23]. Actinobacteria are excellent producers of antibiotics and enzymes, and Streptomyces are the most relevant due to their ability to produce a large number of antibiotics, in addition to other classes of biologically active secondary metabolites. Some antibiotics were identified to have insecticidal activities, including respiratory inhibitors such as antimycin A, patulin and piericidins, protein synthesis inhibitors such as cycloheximide or tenuazonic acid, and membrane-active agents such as some polyene macrolide antibiotics $[12,61,62]$. Streptomyces species can play a very important role in the biocontrol of insect pests, especially mosquitoes, by the direct production of active insecticide compounds [63-66]. Ivermectin is the most well-known insecticide produced by Streptomyces, which was initially used as an antiparasitic agent that has become a systemic treatment for the control of arthropod pests in livestock [67].

We used MALDI-TOF mass spectrometry as well as two sensitive and discriminating PCR systems for the identification of the Streptomyces species we isolated, which revealed that we isolated potential new species or species with sequences that do not exist in the GenBank database. Therefore, the first step in the objective of discovering which compounds are produced is to completely sequence the whole genomes of these species and then proceed to the characterization of the active molecules. The screening of these species for the production of antimicrobial agents also seems to be a track, which is also in progress.

\section{Conclusions}

In conclusion, we isolated noteworthy bacterial species that exhibit remarkable insecticidal activity compared to that of a commercial product. Among them, this was the first time that B. nealsonii was tested against $A$. albopictus larvae, and its supernatant fraction exhibited very high larvicidal 
activity, which means that its secondary metabolites were secreted in the culture medium. We also isolated several species from the Streptomyces genus, of which three were active, and advanced studies are required to characterize the active compounds. Our study reports results that may be still preliminary, but provide potential candidates for the identification of active molecules to be developed for strengthening the biological control of vectors of infectious disease agents transmitted by mosquitoes. It will be very important to test these compounds against other important mosquito species and other insects of medical, veterinary and agricultural interest.

Supplementary Materials: The following are available online at http://www.mdpi.com/2075-4450/11/7/403/s1, Figure S1: Analyses of the spectra obtained from the Streptomyces strains using MALDI Biotyper 3.0 software, Table S1: Dunn pairwise test results. Comparison of insecticidal activity rates between the different isolated species and Bti (AM65-52), Table S2: Accession numbers of the sequenced Streptomyces species.

Author Contributions: Conceptualization, H.D., M.S., D.R. and O.M.; Investigation, H.D.; Methodology, H.D., M.S., D.R., F.F. and O.M.; Software, H.D. and M.S.; Supervision, F.F. and O.M.; Validation, M.S., F.F. and O.M.; Writing —original draft, H.D.; Writing—review and editing, D.R., F.F. and O.M. All authors have read and approved the manuscript.

Funding: This study was supported by the Institut Hospitalo-Universitaire (IHU) Méditerranée Infection, the National Research Agency under the program "Investissements d'avenir", reference ANR-10-IAHU-03. Funding consisted mainly of the doctoral thesis scholarship and all the reagents and materials used in the study.

Acknowledgments: We would like to thank Hacene Medkour for his help with the statistical analyses for our study, Cheikh Sokhna and Sacy Nadarajane for the field activities and Jean-Michel Berenger for providing the commercially obtained Bacillus thuringiensis subsp. israelensis AM65-52.

Conflicts of Interest: The authors declare no conflict of interest. The funders had no role in study design, data collection, and analysis, decision to publish, or preparation of the manuscript.

Availability of Data and Materials: Sequences of sequenced strains are deposited in GenBank. All data generated or analyzed during this study are included in this manuscript and its Supplementary Information Files.

\section{References}

1. Caraballo, H.; King, K. Emergency Department Management of Mosquito-Borne Illness: Malaria, Dengue, and West Nile Virus. Emerg. Med. Pract. 2014, 16, 1-23. [PubMed]

2. Lozano, R.; Naghavi, M.; Foreman, K.; Lim, S.; Shibuya, K.; Aboyans, V.; Abraham, J.; Adair, T.; Aggarwal, R.; Ahn, S.Y.; et al. Global and regional mortality from 235 causes of death for 20 age groups in 1990 and 2010: A systematic analysis for the Global Burden of Disease Study 2010. Lancet 2012, 380, 2095-2128. [CrossRef]

3. WHO. A Global Brief on Vector-Borne Diseases; World Health Organisation: Geneva, Switzerland, 2014. Available online: https://apps.who.int/iris/handle/10665/111008 (accessed on 1 September 2019).

4. Stanaway, J.D.; Shepard, D.S.; Undurraga, E.A.; Halasa, Y.A.; Coffeng, L.E.; Brady, O.J.; Hay, S.I.; Bedi, N.; Bensenor, I.M.; Castañeda-Orjuela, C.A.; et al. The global burden of dengue: An analysis from the Global Burden of Disease Study 2013. Lancet Infect. Dis. 2016, 16, 712-723. [CrossRef]

5. Weiss, D.J.; Lucas, T.C.D.; Nguyen, M.; Nandi, A.K.; Bisanzio, D.; Battle, K.E.; Cameron, E.; Twohig, K.A.; Pfeffer, D.A.; Rozier, J.A.; et al. Mapping the global prevalence, incidence, and mortality of Plasmodium falciparum, 2000-2017: A spatial and temporal modelling study. Lancet 2019, 394, 322-331. [CrossRef]

6. Bartlow, A.W.; Manore, C.; Xu, C.; Kaufeld, K.A.; Del Valle, S.; Ziemann, A.; Fairchild, G.; Fair, J.M. Forecasting Zoonotic Infectious Disease Response to Climate Change: Mosquito Vectors and a Changing Environment. Vet. Sci. 2019, 6, 40. [CrossRef]

7. Flores, H.A.; O'Neill, S.L. Controlling vector-borne diseases by releasing modified mosquitoes. Nat. Rev. Microbiol. 2018, 16, 508-518. [CrossRef]

8. Dahmana, H.; Mediannikov, O. Mosquito-Borne Diseases Emergence/Resurgence and How to Effectively Control It Biologically. Pathogens 2020, 9, 310. [CrossRef]

9. Trevors, J.T.; Barkay, T.; Bourquin, A.W. Gene transfer among bacteria in soil and aquatic environments: A review. Can. J. Microbiol. 1987, 33, 191-198. [CrossRef]

10. Wagman, J.M.; Achee, N.L.; Grieco, J.P. Insensitivity to the Spatial Repellent Action of Transfluthrin in Aedes aegypti: A Heritable Trait Associated with Decreased Insecticide Susceptibility. PLoS Negl. Trop. Dis. 2015, 9, e0003726. [CrossRef] 
11. Mishra, S.K.; Keller, J.E.; Miller, J.R.; Heisey, R.M.; Nair, M.G.; Putnam, A.R. Insecticidal and nematicidal properties of microbial metabolites. J. Ind. Microbiol. 1987, 2, 267-276. [CrossRef]

12. Dhanasekaran, D.; Thangaraj, R. Microbial secondary metabolites are an alternative approaches against insect vector to prevent zoonotic diseases. Asian Pac. J. Trop. Dis. 2014, 4, 253-261. [CrossRef]

13. Lacey, L.A. Bacillus thuringiensis serovariety israelensis and Bacillus sphaericus for mosquito control. J. Am. Mosq. Control Assoc. 2007, 23, 93-109. [CrossRef]

14. Paris, M.; Tetreau, G.; Laurent, F.; Lelu, M.; Despres, L.; David, J.-P. Persistence of Bacillus thuringiensis israelensis (Bti) in the environment induces resistance to multiple Bti toxins in mosquitoes. Pest Manag. Sci. 2011, 67, 122-128. [CrossRef]

15. $\mathrm{Su}, \mathrm{T}$. Resistance and Its Management to Microbial and Insect Growth Regulator Larvicides in Mosquitoes. InTech2016. pp. 135-154. Available online: https://cdn.intechopen.com/pdfs/49420.pdf (accessed on 18 June 2020). [CrossRef]

16. Dahmana, H.; Raoult, D.; Fenollar, F.; Mediannikov, O. Insecticidal Activity of Bacteria from Larvae Breeding Site with Natural Larvae Mortality: Screening of Separated Supernatant and Pellet Fractions. Pathogens 2020, 9, 486. [CrossRef] [PubMed]

17. Kekuda, T.R.P.; Shobha, K.S.; Onkarappa, R. Potent insecticidal activity of two Streptomyces species isolated from the soils of the Western ghats of Agumbe, Karnataka. J. Nat. Pharm. 2010, 1, 30-32. [CrossRef]

18. Pinphanichakarn, P.; Tantithanagorngul, W.; Sujitwanit, A.; Piluk, J.; Tolieng, V.; Petsom, A.; Sangvanich, P.; Palaga, T.; Puthong, S.; Thamchaipenet, A.; et al. Screening for Brine Shrimp Larvicidal Activity of Streptomyces Isolated from Soil and Anti-Tumor Activity of the Active Isolates. Aust. J. Basic Appl. Sci. 2011, $5,15-22$.

19. Anwar, S.; Ali, B.; Qamar, F.; Sajid, I. Insecticidal Activity of Actinomycetes Isolated from Salt Range, Pakistan against Mosquitoes and Red Flour Beetle. Pak. J. Zool. 2014, 46, 83-92.

20. Amin, M.; Rakhisi, Z.; Amanollah Ahmady, Z. Isolation and Identification of Bacillus Species From Soil and Evaluation of Their Antibacterial Properties. Avicenna J. Clin. Microb. Infect. 2015, 2, 23233. [CrossRef]

21. Galarza-Seeber, R.; Latorre, J.D.; Hernandez-Velasco, X.; Wolfenden, A.D.; Bielke, L.R.; Menconi, A.; Hargis, B.M.; Tellez, G. Isolation, screening and identification of Bacillus spp. as direct-fed microbial candidates for aflatoxin B1 biodegradation. Asian Pac. J. Trop. Biomed. 2015, 5, 702-706. [CrossRef]

22. Tariq, A.L.; Sudha, S.; Reyaz, A.L. Isolation and Screening of Bacillus Species from Sediments and Application in Bioremediation. Int. J. Curr. Microbiol. Appl. Sci. 2016, 5, 916-924. [CrossRef]

23. Chen, Y.; Shafi, J.; Li, M.; Fu, D.; Ji, M. Insecticidal activity of endophytic actinomycetes isolated from Azadirachta indica against Myzus persicae. Arch. Biol. Sci. 2018, 70, 349-357. [CrossRef]

24. Nair, K.; Al-Thani, R.; Al-Thani, D.; Al-Yafei, F.; Ahmed, T.; Jaoua, S. Diversity of Bacillus thuringiensis Strains From Qatar as Shown by Crystal Morphology, $\delta$-Endotoxins and Cry Gene Content. Front. Microbiol. 2018, 9, 708. [CrossRef] [PubMed]

25. Seng, P.; Drancourt, M.; Gouriet, F.; La Scola, B.; Fournier, P.; Rolain, J.M.; Raoult, D. Ongoing Revolution in Bacteriology: Routine Identification of Bacteria by Matrix-Assisted Laser Desorption Ionization Time-of-Flight Mass Spectrometry. Clin. Infect. Dis. 2009, 49, 543-551. [CrossRef]

26. Dahmana, H.; Granjon, L.; Diagne, C.; Davoust, B.; Fenollar, F.; Mediannikov, O. Rodents as Hosts of Pathogens and Related Zoonotic Disease Risk. Pathogens 2020, 9, 202. [CrossRef]

27. La Scola, B.; Liang, Z.; Zeaiter, Z.; Houpikian, P.; Grimont, P.A.D.; Raoult, D. Genotypic characteristics of two serotypes of Bartonella henselae. J. Clin. Microbiol. 2002, 40, 2002-2008. [CrossRef] [PubMed]

28. Schulthess, B.; Bloemberg, G.V.; Zbinden, R.; Böttger, E.C.; Hombach, M. Evaluation of the bruker MALDI biotyper for identification of gram-positive rods: Development of a diagnostic algorithm for the clinical laboratory. J. Clin. Microbiol. 2014, 52, 1089-1097. [CrossRef] [PubMed]

29. Chaves, J.V.; Ojeda, C.P.O.; da Silva, I.R.; de Lima Procopio, R.E. Identification and Phylogeny of Streptomyces Based on Gene Sequences. Res. J. Microbiol. 2017, 13, 13-20.

30. Laskaris, P.; Sekine, T.; Wellington, E.M.H.; Herrera-Estrella, A. Diversity Analysis of Streptomycetes and Associated Phosphotranspherase Genes in Soil. PLoS ONE 2012, 7, e35756. [CrossRef]

31. Kumar, S.; Stecher, G.; Tamura, K. MEGA7: Molecular Evolutionary Genetics Analysis Version 7.0 for Bigger Datasets. Mol. Biol. Evol. 2016, 33, 41-48. [CrossRef] 
32. Milne, I.; Lindner, D.; Bayer, M.; Husmeier, D.; McGuire, G.; Marshall, D.F.; Wright, F. TOPALi v2: A rich graphical interface for evolutionary analyses of multiple alignments on HPC clusters and multi-core desktops. Bioinformatics 2009, 25, 126-127. [CrossRef]

33. WHOCDCPE \& WHOPES Guidelines for Laboratory and Field Testing of Mosquito Larvicides. 2005. Available online: https://apps.who.int/iris/bitstream/handle/10665/69101/WHO_CDS_WHOPES_GCDPP_ 2005.13.pdf? sequence $=1 \&$ isAllowed $=y$ (accessed on 19 June 2019).

34. Yarbrough, M.L.; Lainhart, W.; Burnham, C.A.D. Identification of Nocardia, Streptomyces, and Tsukamurella using MALDI-TOF MS with the Bruker Biotyper. Diagn. Microbiol. Infect. Dis. 2017, 89, 92-97. [CrossRef] [PubMed]

35. Vachon, V.; Laprade, R.; Schwartz, J.L. Current models of the mode of action of Bacillus thuringiensis insecticidal crystal proteins: A critical review. J. Invertebr. Pathol. 2012, 111, 1-12. [CrossRef]

36. Gratz, N.G. Critical review of the vector status of Aedes albopictus. Med. Vet. Entomol. 2004, 18, $215-227$. [CrossRef] [PubMed]

37. Medlock, J.M.; Hansford, K.M.; Versteirt, V.; Cull, B.; Kampen, H.; Fontenille, D.; Hendrickx, G.; Zeller, H.; Van Bortel, W.; Schaffner, F. An entomological review of invasive mosquitoes in Europe. Bull. Entomol. Res. 2015, 105, 637-663. [CrossRef]

38. Raoult, D.; Abat, C. Developing new insecticides to prevent chaos: The real future threat. Lancet Infect. Dis. 2017, 17, 804-805. [CrossRef]

39. Collins, E.; Vaselli, N.M.; Sylla, M.; Beavogui, A.H.; Orsborne, J.; Lawrence, G.; Wiegand, R.E.; Irish, S.R.; Walker, T.; Messenger, L.A. The relationship between insecticide resistance, mosquito age and malaria prevalence in Anopheles gambiae s.l. from Guinea. Sci. Rep. 2019, 9, 1-12. [CrossRef] [PubMed]

40. World Malaria Report Relief Web. Available online: https:/reliefweb.int/report/world/world-malaria-report2017 (accessed on 30 August 2019).

41. Kharel, M.K.; Shepherd, M.D.; Nybo, S.E.; Smith, M.L.; Bosserman, M.A.; Rohr, J. Isolation of Streptomyces species from soil. Curr. Protoc. Microbiol. 2010. [CrossRef]

42. Saadoun, I.; Gharaibeh, R. The Streptomyces flora of Badia region of Jordan and its potential as a source of antibiotics active against antibiotic-resistant bacteria. J. Arid Environ. 2003, 53, 365-371. [CrossRef]

43. George, M.; George, G.; Hatha, A.A.M. Diversity and antibacterial activity of actinomycetes from wetland soil. S. Pac. J. Nat. Appl. Sci. 2010, 28, 52. [CrossRef]

44. Dezfully, N.K.; Ramanayaka, J.G. Isolation, Identification and Assessment of the Antimicrobial Activity of Streptomyces flavogriseus, Strain ACTK2, From a Soil Sample From Kodagu, Karnataka State in India. Jundishapur J. Microbiol. 2015, 8, e15107.

45. Aslim, B.; Beyatli, Y. Determination of Some Properties of Bacillus Isolated from Soil. Turk. J. Biol. 2002, 26, $41-48$.

46. Radhakrishnan, R.; Hashem, A.; Abd Allah, E.F. Bacillus: A biological tool for crop improvement through bio-molecular changes in adverse environments. Front. Physiol. 2017, 8, 667. [CrossRef] [PubMed]

47. Palma, L.; Muñoz, D.; Berry, C.; Murillo, J.; Caballero, P. Bacillus thuringiensis toxins: An overview of their biocidal activity. Toxins 2014, 6, 3296-3325. [CrossRef] [PubMed]

48. Aïdara-Kane, A.; Fontenille, D.; Lochouarn, L.; Cosmao-Dumanoir, V.; Lecadet, M. Caractérisation de souches de Bacillus entomopathogènes isolées au Sénégal et étude de leur toxicité pour les vecteurs du paludisme. Dakar-Médical 1998, 43, 170-173.

49. Cheong, H.; Dhesi, R.K.; Gill, S.S. Marginal cross-resistance to mosquitocidal Bacillus thuringiensis strains in Cry11A-resistant larvae: Presence of Cry11A-like toxins in these strains. FEMS Microbiol. Lett. 2006, 153, 419-424. [CrossRef]

50. Amorim, L.B.; de Barros, R.A.; de Melo Chalegre, K.D.; de Oliveira, C.M.F.; Narcisa Regis, L.; Silva-Filha, M.H.N.L. Stability of Culex quinquefasciatus resistance to Bacillus sphaericus evaluated by molecular tools. Insect Biochem. Mol. Biol. 2010, 40, 311-316. [CrossRef]

51. Wirth, M.C. Mosquito Resistance to Bacterial Larvicidal Toxins. Open Toxicol. J. 2010, 3, 101-115. [CrossRef]

52. Darriet, F.; Hougard, J.-M. An isolate of Bacillus circulans toxic to mosquito larvae. J. Am. Mosq. Control Assoc. 2002, 18, 65-67.

53. Favret, M.E.; Yousten, A.A. Insecticidal activity of Bacillus laterosporus. J. Invertebr. Pathol. 1985, 45, 195-203. [CrossRef] 
54. Orlova, M.V.; Smirnova, T.A.; Ganushkina, L.A.; Yacubovich, V.Y.; Azizbekyan, R.R. Insecticidal activity of Bacillus laterosporus. Appl. Environ. Microbiol. 1998, 64, 2723-2725. [CrossRef]

55. Sevim, A.; Demirbağ, Z.; Demir, İ. A new study on the bacteria of Agrotis segetum Schiff. (Lepidoptera: Noctuidae) and their insecticidal activities. Res. Artic. Turk. J. Agric. 2010, 34, 333-342.

56. Oulebsir-Mohandkaci, H.; Khemili, S. Antagonistic activity of two Bacillus sp. strains isolated from an algerian soil towards the migratory Locust locusta migratoria (linnaeus 1758) Production and characterization of a Lipopeptide Biosurfactant by a some Bacillus sp.strains View project Isol. Agric. For. 2016, 62, 145-154.

57. Venkateswaran, K.; Kempf, M.; Chen, F.; Satomi, M.; Nicholson, W.; Kern, R. Bacillus nealsonii sp. nov., isolated from a spacecraft-assembly facility, whose spores are $\gamma$-radiation resistant. Int. J. Syst. Evol. Microbiol. 2003, 53, 165-172. [CrossRef] [PubMed]

58. Nathani, N.M.; Duggirala, S.M.; Bhatt, V.D.; Kapatel, J.; Joshi, C.G. Genomic analysis of a novel strain of Bacillus nealsonii, isolated from Surti buffalo rumen. Adv. Biosci. Biotechnol. 2014, 5, 235-245. [CrossRef]

59. Yu, P.; Chen, Y. Purification and characterization of a novel neutral and heat-tolerant phytase from a newly isolated strain Bacillus nealsonii ZJ0702. BMC Biotechnol. 2013, 13, 78. [CrossRef] [PubMed]

60. David, A.; Singh Chauhan, P.; Kumar, A.; Angural, S.; Kumar, D.; Puri, N.; Gupta, N. Coproduction of protease and mannanase from Bacillus nealsonii PN-11 in solid state fermentation and their combined application as detergent additives. Int. J. Biol. Macromol. 2018, 108, 1176-1184. [CrossRef]

61. Zizka, Z.; Weiser, J.; Blumauerova, M.; Jizba, J. Ultrastructural effects of macrotetrolides of Streptomyces griseus LKS-1 in tissues of Culex pipiens larvae. Cytobios 1989, 58, 85-91.

62. Hussain, A.A.; Mostafa, S.A.; Ghazal, S.A.; Ibrahim, S.Y. Studies on antifungal antibiotic and bioinsecticidal activities of some actinomycete isolates. Afr. J. Mycol. Biotechnol. 2002, 10, 63-80.

63. Box, S.J.; Cole, M.; Yeoman, G.H. Prasinons A and B: Potent Insecticides from Streptomyces prasinus. Appl. Environ. Microbiol. 1973, 26, 699-704. [CrossRef]

64. Saurav, K.; Rajakumar, G.; Kannabiran, K.; Rahuman, A.A.; Velayutham, K.; Elango, G.; Kamaraj, C.; Zahir, A.A. Larvicidal activity of isolated compound 5-(2,4-dimethylbenzyl) pyrrolidin-2-one from marine Streptomyces VITSVK5 sp. against Rhipicephalus (Boophilus) microplus, Anopheles stephensi, and Culex tritaeniorhynchus. Parasitol. Res. 2013, 112, 215-226. [CrossRef]

65. El-bendary, M. Larvicidal activity of extracellular secondary metabolites of of Streptomyces microflavus against Culex pipien. Can. J. Pure Appl. Sci. 2014, 4, 1021-1026.

66. Paulraj, M.G.; Kumar, P.S.; Ignacimuthu, S.; Sukumaran, D. Natural insecticides from actinomycetes and other microbes for vector mosquito control. In Herbal Insecticides, Repellents and Biomedicines: Effectiveness and Commercialization; Springer International Publishing: Cham, Switzerland, 2016; pp. 85-99, ISBN 9788132227045.

67. Jackson, H.C. Ivermectin as a systemic insecticide. Parasitol. Today 1989, 5, 146-156. [CrossRef] 